\title{
Peningkatan hasil belajar keliling bangun datar melalui strategi belajar kooperatif tipe STAD di sekolah dasar
}

\author{
Sukinem Sukinem $\left.{ }^{*}\right)$ \\ Sekolah Dasar Negeri 04 Lunang
}

\begin{tabular}{l}
\hline \hline Article Info \\
\hline Article history: \\
Received April $13^{\text {th }}, 2021$ \\
Revised May $12^{\text {th }}, 2021$ \\
Accepted Jun $18^{\text {th }}, 2021$ \\
\hline
\end{tabular}

\section{Keyword:}

Hasil belajar

Belajar kooperatif tipe STAD

\begin{abstract}
Pada pelaksanaan strategi belajar kooperatif tipe STAD ini, terdiri dari lima langkah yaitu penyajian kelas, kegiatan belajar kelompok, tes individu, penentuan peningkatan skor individu, dan penghargaan kelompok. Penelitian ini bertujuan untuk meningkatkan hasil belajar keliling bangun datar bagi siswa kelas III UPT SDN 04 Lunang Kec. Lunang Pesisir Bayang Kabupaten Pesisir Selatan yang dilaksanakan pada semerter II tahun ajaran 2019/2020, dan yang menjadi subjek tertelitinya siswa kelas IIIB. Pendekatan yang digunakan pada penelitian ini adalah pendekatan kualitatif dan jenis penelitian ini adalah Penelitian Tindakan Kelas (Classroom Action Research). Hasil penelitian yang dilakukan terhadap 28 orang siswa sebagai berikut: (1) Tindakan siklus I pertemuan I, dengan materi rumus keliling dan menyelesaikan soal-soal yang berhubungan dengan persegi dan hasil belajar yang diperoleh siswa 6,9 (2) Tindakan siklus I pertemuan II, dengan materi menyelesaikan soal cerita yang berkaitan dengan mencara keliling persegi dan hasil belajar yang diperoleh 7,7 . Secara umum pelaksanaan pada siklus I pertemuan II ini bila dibanding siklus I pertemuan I sudah lebih baik (3) Tindakan siklus II, tindakan ini dilakukan untuk menbuktikan apakah hasil belajar yang diperoleh siswa tetap meningkat, dengan materi mencari rumus keliling persegi panjang dan menyelsaikan soal-soal yang berkaitan dengan keliling persegi panjang dan hasil belajar yang diperoleh 8,6. Dari hasil belajar tersebut terbuktilah bahwa penggunaan strategi belajar kooperatif tipe STAD dapat meningkatkan hasil belajar siswa.
\end{abstract}

(C) 2021 The Authors. Published by IICET.

This is an open access article under the CC BY-NC-SA license (https://creativecommons.org/licenses/by-nc-sa/4.0)

\section{Corresponding Author:}

Sukinem Sukinem,

Sekolah Dasar Negeri 04 Lunang

Email: sukinem@gmail.com

\section{Pendahuluan}

Materi mencari keliling bangun datar sederhana merupakan salah satu kompetensi dasar yang harus dikuasai siswa SD khususnya di kelas III. Untuk itu, menurut Sri (2006:127) "Konsep mencari keliling suatu bangun geometri dapat ditanamkan kepada siswa SD melalui kegiatan siswa." Hal ini dilakukan untuk mencegah siswa memahami konsep keliling secara verbal atau hannya dengan menghafal rumus mencari keliling.

Salah satu fakta yang ditemui ketika guru meminta siswa mencari keliling persegi panjang, yang diketahui panjang $6 \mathrm{~cm}$ dan lebar $4 \mathrm{~cm}$, dan jawaban yang diberikan salah seorang siswa adalah $24 \mathrm{~cm}$ karena $6 \mathrm{~cm} \times 4$ $\mathrm{cm}$. Melihat hal ini, jelaslah bahwa masih ada siswa yang belum dapat membedakan konsep keliling persegi panjang dengan konsep luas persegi panjang. Padahal, dari keterangan guru, materi ini telah diajarkan 
sebelumnya dan jawaban yang seharusnya diberikan siswa adalah $20 \mathrm{~cm}$ karena rumus keliling persegi panjang $2 \mathrm{p}+21=2 \times 6 \mathrm{~cm}+2 \times 4 \mathrm{~cm}=20 \mathrm{~cm}$.

Dalam pelaksanaan strategi belajar kooperatif tipe STAD banyak terdapat manfaat, baik bagi siswa yang cepat memahami materi pelajaran maupun bagi siswa yang lambat memahami materi pelajaran. Bagi siswa yang cepat memahami materi pelajaran dapat meningkatkan kepercayaan diri dan tanggung jawab untuk membimbing teman-temanya dalam menguasai materi pelajaran karena nilai kelompok bergantung pada nilai rata-rata masing-masing anggota kelompok. Sedangkan bagi siswa yang lambat menguasai materi pelajaran, dapat belajar dari teman satu kelompok yang terlebih dahulu memahami materi pelajaran karena belajar dari dari teman sebaya cenderung lebih cepat dimengerti siswa dibanding belajar dari orang dewasa seperti guru.

Dengan melihat banyak manfaat dari pelaksanaan strategi belajar kooperatif tife STAD, diperkirakan strategi belajar ini dapat dilaksanakan, apalagi strategi belajar kooperatif tipe STAD ini adalah strategi yang paling sederhana bila dibanding strategi belajar kooperatif jenis lain. Apalagi bagi guru yang baru belajar melaksanakan strategi belajar kooperatif. Berdasarkan uraian yang telah dijabarkan sebelumnya, maka penulis berkeinginan melaksanakan penelitian tindakan kelas (PTK) dengan judul "Peningkatan Hasil Belajar Keliling Bangun Datar Melalaui Strategi Belajar Kooperatif Tipe STAD di Kelas III UPT SDN 04 Lunang Kec. Lunang Kabupaten Pesisir Selatan"

\section{Metode}

Penelitian ini dilaksanakan di UPT SDN 04 Lunang Kec. Lunang Kabupaten Pesisir Selatan. Penelitian tindakan kelas ini dilakukan pada siswa kelas III UPT SDN 04 Lunang Kec. Lunang, dengan jumlah siswa 28 orang, 18 orang siswa laki-laki dan 10 orang siswa perempuan. Waktu mengadakan penelitian ditetapkan pada bulan Mei s.d Juni tahun ajaran 2019/2020. Terhitung dari waktu perencanaan sampai penulisan laporan hasil penelitian. Sedangkan pelaksanaan dari penelitian ini dimulai dari tanggal 19 Mei 2020 dan berakhir tanggal 10 Juni 2020. Pendekatan yang digunakan dalam penelitian ini adalah pendekatan kualitatif. Sementara itu, jenis penelitian yang dilaksanakan pada penelitian ini adalah penelitian tindakan kelas (Classroom Action Research).

Dalam proses penelitian tindakan kelas, merupakan proses daur ulang atau dilakukan dalam beberapa siklus. Pernyataan ini didukung oleh Suharsimi (2006:104) yang menekankan "Daur ulang dalam penelitian diawali dengan perencanaan (planning), penerapan tindakan (observasi and evaluation), dan melakukan refleksi (reflecting) dan seterusnya sampai perbaikan atau peningkatan yang diharapkan tercapai (kriteria keberhasilan)."

Selanjutnya konsep ini juga senada dengan pendapat Kurt Lewin (dalam Tatang, 2008:6) yang mengungkapkan "Konsep inti penelitian tindakan kelas dalam satu siklus terdiri dari empat langkah, yaitu 1) perencanan (planning), 2) Aksi atau tindakan (acting), 3) Observasi (observasing), dan refleksi (reflecting)." Dari kedua pendapat tersebut, dapat disimpulkan proses penelitian tindakan merupakan daur ulang atau siklus yang dimulai dari aspek perencanaan, melaksanakan tindakan sesuai rencana, melakukan pengamatan atau observasi terhadap tindakan dan melaksanakan refleksi atau perenungan terhadap perencanaan tindakan dan kesuksesan hasil yang diperoleh.

\section{Prosedur penelitian}

Kegiatan penelitian tindakan kelas terdiri dari beberapa tahapan pembelajaran. Masing-masing tahapan tersebut diuraikan sebagai berikut:

a. Refleksi awal / Studi pendahuluan

Penelitian ini diawali dengan menggunakan studi pendahuluan berupa observasi awal terhadap pembelajaran matematika di kelas III SD terteliti. Hal ini dilakukan untuk mengetahui permasalahan yang dihadapi guru dan siswa berkaitan proses pembelajaran Matematika khususnya tentanh pembelajaran keliling bangun datar di kelas III SD.

b. Penyusunan rencana tindakan / perencanaan

Berdasarkan rumusan masalah hasil studi pendahuluan, peneliti bersama guru membuat rencana tindakan yang akan dilakukan. Tindakan ini berupa pembelajaran Matematika tentang keliling bangun datar dengan strategi belajar kooperatif tipe STAD dengan kegiatan sebagai berikut:

1) Menetapkan jadwal selama penelitian

2) Mengkaji KTSP 2006 Matematika SD dan buku paket Matematika kelas III SD serta buku Matematika lain yang relevandengan materi yang diajarkan. 
3) Menyusun rencana tindakan berupa model rancangan pembelajaran. Hal ini meliputi: (a) Standar Kompetensi, (b) Kompetensi Dasar, (c) Menentukan indikator pembelajaran berdasarkan kompetensi dasar yang diambil dan mencakup tiga ranah pembelajaran dengan menggunakan kata-kata operasional, (d) Mengembangkan materi dalam bentuk uraian materi, (e) Menyusun langkah-langkah pembelajaran, (f) Memilih dan menetapkan media sumber belajar dan (g) Merancang evaluasi pembelajaran.

4) Membuat LKS yang akan dipergunakan dalam proses pembelajaran

5) Menyusun lembar observasi untuk mencatat semua aktivitas baik yang dilakukan siswa maupun guru.

6) Mendiskusikan dengan guru tentang cara pengumpulkan data dalam pelaksanaan observasi saat kegiatan dilakukan, agar tidak terjadi penyimpangan dalam pengambilan data. Waktu yang digunakan untuk berdiskusi adalah waktu luang yang ada bagi guru, yaitu pada jam istirahat, pada waktu pelajaran agama dan olah raga serta bisa juga ketika akhir pelajaran.

c. Tahap pelaksanaan dan pengamatan

1) Tahap pelaksanaan tindakan

Tahap ini dimulai dari pelaksanaan pembelajaran keliling bangun datar melalui strategi belajar kooperatif tipe STAD. Kegiatan ini dilakukan oleh guru sebagai observer dan peneliti sebagai praktisi. Praktisi melaksanakan proses pembelajaran di kelas berupa kegiatan interaksi antara guru dan siswa, siswa dengan siswa. Tahap pelaksanaan tindakan ini dilaksanakan tindakan ini dilaksanakan dalam 2 siklus dan setiap siklus mempunyai materi tersendiri yang diambil berdasarkan KTSP 2013 SD. Fokus tindakan setiap siklus berupa penggunaan strategi belajar kooperatif tipe STAD.

2) Tahap pengamatan

Pengamatan dilakukan secara terus menerus mulai dari siklus I sampai dengan siklus II. Pengamatan yang dilakukan pada siklus I dapat mempengaruhi penyusunan tindakan pada siklus selanjutnya. Hasil pengamatan ini kemudian didiskusikan dengan guru dan untuk diadakan perencanaan siklus II.

3) Tahap refleksi

Setelah pengataman selesai dilakukan, kemudian praktisi dan guru melakukan kegiatan refleksi pada akhir tiap tindakan. Dalam tahap ini guru dan peneliti mendiskusikan tindakan yang baru dilaksanakan. Hal-hal yang didiskusikan adalah: 1) Menganalisis tindakan yang baru dilakukan; 2) Mengulas dan menjelaskan perbedaan rencana dan pelaksaan tindakan yang telah dilakukan; 3) Melakukan interpensi, pemaknaan dan penyimpulan data yang diperoleh. Hasil refleksi bersama ini dimanfaatkan sebagai masukan pada tindakan selanjutnya. Selain itu, hasil kegiatan refleksi bersama ini digunakan untuk menyusun kesimpulan terhadap hasil tindakan I dan II.

\section{Data dan sumber data}

Data dalam penelitian ini merupakan data primer karena berupa hasil pengamatan dari setiap tindakan pembelajaran keliling bangun datar dengan strategi belajar kooperatif tipe STAD pada siswa kelas III SD terteliti. Pernyataan ini didukung oleh pendapat Ihat (2007:192) mengungkapkan "Data primer adalah data yang diperoleh atau dikumpulkan oleh peneliti lansung dari sumber utama data." Data ini berkaitan dengan perencanaan, pelaksanaan, dan hasil belajar yang berupa informasi sebagai berikut: 1) Pelaksanaan pembelajaran yang berhubungan dengan prilaku guru dan yang meliputi interaksi proses pembelajaran antara siswa dengan guru dan siswa dengan siswa dalam pembelajaran keliling bangun datar; 2) Evaluasi pembelajaran keliling bangun datar yang berupa evaluasi proses maupun evaluasi hasil; 3) Hasil tes siswa baik sebelum maupun sesudah pelaksanaan tindakan pembelajaran keliling bangun datar.

Sumber data dalam penelitian ini merupakan subjek dimana tempat data diperoleh. Pernyataan ini diperkuat oleh pendapat Suharsimi (2006:129) bahwa "Apabila peneliti menggunakan teknik observasi, maka sumber datanya dapat berupa benda, gerak, atau proses sesuatu." Untuk itu sumber data dalam penelitian ini diperoleh dari subjek terteliti, yaitu guru dan siswa kelas III UPT SDN 04 Lunang Kec. Lunang Kabupaten Pesisir Selatan selama melaksanakan atrategi pembelajaran koperatif tipe STAD.

\section{Teknik Pengunpulan Data dan Instrumen Penelitian}

Teknik pengumpulan atau penyusunan data penelitian merupakan pola terpenting dalam prosedur penelitian. Data penelitian ini dikumpulkan dengan menggunakan lembar observasi, hasil tes dan dokumentasi.

\section{Analisis Data}

Tahap analisis dilakukan berulang-ulang begitu data selesai dikumpulkan pada setiap pengumpulan data dalam setiap tindakan. Tahap analisis data ini dapat diuraikan sebagai berikut: menelaah data yang terkumpul dengan melakukan transkripsi hasil pengamatan, penyeleksian dan pemilihan data. 
Kemudian data direduksi melalui pengkategorian dan pengklasifikasian sesuai dengan fokus masing-masing. Dalam penyeleksian ini, dapat diketahui mana yang relevan dan mana yang tidak relevan. Kemudian data tersebut disajikan secara terpadu. Barulah terakhir dengan menyimpulkan hasil penelitian.

\section{Pembahasan}

\section{Hasil Penelitian}

\section{Hasil dan Temuan Penelitian Siklus I (Pertemuan I)}

1. Perencanaan

Perencanaan dalam pelaksanaan tindakan dimulai dengan mengambil satu kompetensi dasar kemudian dikembangkan dalam indikator dan dilanjutkan dengan membuat RPP yang utuh, menetapkan media yang cocok dalam pembelajaran dan berdiskusi dengan teman sejawat tentang waktu pelaksanaan tindakan.

\section{Pelaksanaan}

Pada langkah pertama dalam strategi belajar kooperatif tipe STAD adalah penyajian kelas yang dilakukan dengan menyajikan materi yang akan dipelajari yaitu menemukan rumus keliling persegi. Tujuan dari penyajian kelas ini untuk lebih memfokuskan siswa terhadap materi yang akan didiskusikan, kegiatan ini berlansung selama 20 menit.

Langkah berikutnya adalah kegiatan belajar bersama dalam kelompok yang merupakan langkah terpenting dalam strategi belajar kooperatif tipe STAD. Pengorganisasian siswa didasarkan atas tingkat akademik dan jenis kelamin. Disini guru membagi siswa sebanyak 9 kelompok, yang masing-masing kelompok terdiri dari 3 sampai 4 orang siswa.

Guru membagi-bagikan dua lembar LKS dan satu lembar jawaban untuk masing-masing kelompok. Disamping itu guru juga memberikan ringkasan materi guna semakin memfokuskan siswa dalam diskusi kelompok untuk menjawab LKS yang diberikan. Setelah siswa selesai melaksanakan diskusi, salah satu kelompok diminta untuk menuliskan hasil diskusi kelompoknya dipapan tulis. Guru meluruskan jawaban siswa dengan kunci jawaban yang telaah disediakan. Masing-masing kelompok memperbaiki jawaban yang dibuat berdasarkan kunci jawaban.

Langkah selanjutnya tes individual, guru memberikan tes kepada siswa dan dikerjakan secara individual. Kemudian guru memeriksa lembar jawaban yang telah dibuat siswa. Dalam kegiatan ini guru menghitung peningkatan skor yang didapat siswa dari skor dasar sebelum pembelajaran. Untuk menentukan kelompok yang memperoleh penghargaan dilakukan guru dengan melihat kelompok mana yang memiliki nilai tertinggi.

\section{Pengamatan}

Teman sejawat berperan mengamati peneliti saat melakukan tindakan dan teman sejawat bertugas mengamati kegiatan siswa selama proses pembelajaran. Dalam kegiatan ini, observer melaksanakan tugasnya dibantu dengan lembaran pengamatan kegiatan yang diisi dengan memberi tanda ceklist baik pada aspek pengamatan guru maupun siswa dengan kriteria taraf keberhasilan yaitu Sangat Baik (SB), Baik (B), Cukup (C), Kurang (K).

1) Penilaian RPP

Penilaian RPP mencakup lima hal yaitu kejelasan perumusan tujuan pembelajaran, pemilihan materi ajar dan pengorganisasian materi ajar, pemilihan sumber atau media belajar, kejelasan proses pembelajaran, dan penilaian hasil belajar. Dari penilaian pengamatan terhadap pelaksanaan tindakan dengan kesesuaian RPP dapat diambil kesimpulan.

Penilaian terhadap RPP yang diberikan oleh pengamat adalah 10 dengan persentase $50 \%$. Selanjutnya jika disesuaikan kriteria keberhasilan menurut BNSP (2006:12), maka penilaian yang diberikan terhadap RPP tergolong belum tuntas. Hal ini karena masih banyak kegiatan yang telah tercantum dalam RPP, tetapi tidak dengan baik.

2) Dari segi aktivitas guru dalam proses pembelajaran

Penilaian yang diberikan pengamat terhadap aspek guru adalah 17 atau dengan persentase $53 \%$. Bila disesuaikan dengan kriteria keberhasilan menurut BNSP (2006:12), maka penilaian dari pengamat terhadap aspek guru pada pertemuan I ini belum tuntas.

3) Aktivitas siswa dalam proses pembelajaran

Pada kegiatan akhir, saat guru memberikan tes individu hanya sebahagian kecil siswa yang dapat menyelesaikan tes yang diberikan guru. Sehingga peningkatan nilai rata-rata siswa dalam kelompok 
dari skor dasar rendah. Oleh karena itu, penilaian yang diberikan pengamat terhadap aspek siswa adalah 17 atau dengan persentase $61 \%$.

Dari pengamatan terhadap aktivitas siswa tersebut, dapat diketahui bahwa proses pembelajaran yang dilakukan belum berhasil. Berdasarkan kriteria keberhasilan menurut BNSP (2006:12), maka penilaian terhadap aspek siswa adalah belum tuntas.

4. Refleksi

Kegiatan refleksi dilakukan secara kolaboratif antara praktisi dan guru kelas (observer) pada setiap akhir pembelajaran. Pada kesempatan ini temuan dan hasil pengamatan peneliti dibahas bersama. Refleksi tindakan siklus I pertemuan I ini mencakup refloeksi terhjadap perencanaan, pelaksanaan, evaluasi, dan hasil yang diperoleh nsiswa.

Dari hasil paparan data siklus I pertemuan I diketahui bahwa pelaksanaan pembelajaran keliling dengan strategi belajar kooperatif tipe STAD belum terlaksanan dengan baik.

Dari hasil belajar yang dicapai siswa pada siklus I petrtemuan I ini, terlihat sudah ada peningkatan hasil belajar yang diperoleh siswa dari sebelum perencanaan pembelajaran yaitu dari 6,1 menjadi 6,9. namun halk ini belum maksiomal. Hal ini dapat dilihat dari berbagai aspek baik mperencanaan, pelaksanaan. Dan aktivitas, serta hasil belum sesuai dengan hasil harapan. Padahal materi yang disamapaikan masih tergolong rendah.

Hal tersebut terjadi katrena siswa belum pernah melaksanakan belajar dalam eklompok, sehingga banyak siswa yang kurang memahami fungsi dan peranannya dalam diskusi kelompok. Apalagi dengan langkah strategi belajar yang dilaksanakan guru, seperti kegiatan belajar kelompok untuk mendiskusikan materi pelajaran yang sedang dipelajari. Selain itu pengaturan posisi duduk siswa dalam kelompok yang memakan waktu yang cukup lama. Disamping itu, guru baru pertama kali melaksanakan strategi belajar kooperatif tipe STAD.

Peneliti akan melaksanakan kembali strategi berlajar kooperatif tipe STAD ini pada siklus I (pertemuan II) pada materi pelajaran yang sama dengan lebih baik, yaitu menyelesaikan soal-soal yang berkaitan dengan keliling persegi. Materi ini merupakan kelanjutan materi dari siklus I pertemuan I.

Rencana perbaikan yang akan dilaksanakan antara lain peneliti berusaha menguasai dan melaksanakan setiap langkah dari strategi belajar kooperatif tipe STAD dengan baik, terutama ketika penyajian kelas siswa diharuskan untuk memperhatikan dengan baik karena sangat berpengaruh dalam bagi siswa dalam menyelesaikan LKS kelompok dan tes individu. Selain itu, peneliti menyediakan waktu luang diluar jam belajar untuk melatih siswa bagaimana cara belajar kelompok yang baik dengan menjelaskan ketentuan-ketentuan yang harus dijalankan selama diskusi kelompok dan menjelaskan bahwa nilai kelompok bergantung pada peningkatan nilai rata-rata anggota kelompok. Oleh karena itu diharuskan setiap anggota kelompok aktif berpartisipasi selama diskusi.

Disamping itu peneliti berusaha mengelola penggunaan waktu dan pengaturan kelas menjadi lebih baik, sehingga tidak ada waktu yang terbuang hanya untuk satu langkah pembelajran saja. Sedangkan untuk mengatasi banyaknya waktu luang dalam mengatur terlebih dahulu posdisi duduk siswa sebelum mereka memasuki ruang kelas. Sehingga ketika memasuki kelas siswa lansung menempati tempat duduknya secara teratur, dan untuk melaksanakan proses pembelajaran peneliti juga akan melengkapi dengan format penilaian individu dan kelompok.

\section{Hasil dan Temuan Penelitian Siklus I (Pertemuan II)}

\section{Perencanaan}

Perencanaan dalam pelaksanaan tindakan dimulai dengan mengambil satu kompetensi dasar kemudian dikembangkan dalam indikator dan dilanjutkan dengan membuat RPP yang utuh, menetapkan media yang cocok dalam pembelajaran dan berdiskusi dengan guru kelastentang waktu pelaksanaan tindakan.

2. Pelaksanaan

Langkah pertama dalam strategi belajar kooperatif tipe STAD adalah penyajian kelas. Pada penyajian kelas ini guru menyajikan yang akan dipelajari yaitu menemukan rumus keliling persegi dalam menyelesaikan soal. Tujuan dari penyajian kelas ini untuk lebih memfokuskan siswa terhadap materi yang akan didiskusikan, kegiatan ini berlansung selama 20 menit.

Langkah berikutnya adalah kegiatan belajar bersama dalam kelompok yang merupakan langkah terpenting dalam strategi belajar kooperatif tipe STAD. Dalam langkah ini siswa dikelompokkan dalam kelompok belajar yang didasarkan atas tingkat akademik dan jenis kelamin yang berbeda. Disini guru membagi siswa sebanyak 9 kelompok, yang masing-masing kelompok terdiri dari 3 sampai 4 orang siswa 
Setiap kelompok diberi lembar LKS sesuai dengan jumlah anggota kelompok dan satu lembar jawaban, serta ringkasan materi supaya lebih memfokuskan siswa dalam diskusi kelompok dan untuk menyelesaikan LKS yang diberikan. Disamping itu, guru selalu mengamati setiap kegiatan siswa selama diskusi dengan lembar pengamatan siswa.

Setelah siswa selesai melaksanakan diskusi, semua kelompok diminta untuk menuliskan hasil diskusi kelompoknya dipapan tulis dan guru meminta tanggapan dari kelompok lain atas jawaban yang telah ditulis dipapan tulis. Untuk meluruskan jawaban siswa, guru menggunakan kunci jawaban yang telah disediakan. Masing-masing kelompok memperbaiki jawaban yang dibuat dengan kunci jawaban yang diberikan guru.

Langkah selanjutnya tes individual, guru memberikan tes kepada siswa. Selama mengerjakan tes siswa tidak boleh saling membantu dan harus dikerjakan secara sendiri-sendiri. Kemudian tes yang telah dikerjakan siswa diperiksa guru. Dalam kegiatan ini guru menghitung peningkatan skor yang didapat siswa dari skor dasar sebelum pembelajaran. Cara guru menentukan kelompok yang memperoleh penghargaan didasarkan total skor peningkatan individu dalam kelompok.

3. Pengamatan

Guru kelas berperan mengamati peneliti saat melakukan tindakan dan teman sejawat bertugas mengamati kegiatan siswa selama proses pembelajaran. Observer dalam melaksanakan tugasnya dibantu dengan lembaran pengamatan kegiatan yang diisi dengan memberi tanda ceklist baik pada aspek pengamatan guru maupun siswa dengan kriteria taraf keberhasilan yaitu Sangat Baik (SB), Baik (B), Cukup (C), Kurang (K).

a. Penilaian RPP

Penilaian RPP mencakup lima hal yaitu kejelasan perumusan tujuan pembelajaran, pemilihan materi ajar dan pengorganisasian materi ajar, pemilihan sumber atau media belajar, kejelasan proses pembelajaran, dan penilaian hasil belajar. Dari penilaian pengamatan terhadap pelaksanaan tindakan dengan kesesuaian RPP dapat diambil kesimpulan.

Penilaian terhadap RPP yang diberikan oleh pengamat adalah 13 dengan persentase $65 \%$. Untuk lebih jelas dapat dilihat pada lampiran 16 halaman 139. Berdasarkan kriteria keberhasilan menurut BNSP (2006:12), maka penilaian yang diberikan terhadap RPP adalah belum tuntas. Tetapi bila dibanding pertemuan I kesesuai antara perencaraan dengan pelaksanaan lebih baik.

b. Dari segi aktivitas guru dalam proses pembelajaran

Dari keseluruhan kegiatan yang dilakukan peneliti pada siklus I pertemuan II, masih ada beberapa kekurangan. Dengan belum berhasilnya proses pembelajaran yang dilakukan, sangat berpengaruh sekali terhadap hasil belajar yang dicapai siswa. Kekurangan-kekurangan pada pertemuan ini, memberikan masukan kepada peneliti dalam menigkatkan keberhasilan dalam proses pembelajran selanjutnya.

Penilaian yang diberikan pengamat terhadap aspek guru adalah 21 atau dengan persentase $66 \%$. Berdasarkan kriteria keberhasilan menurut BNSP (2006:12), maka penilaian pengamat terhadap aspek guru adalah belum tuntas.

c. Aktivitas siswa dalam proses pembelajaran

Keterlibatan siswa juga diamati, kegiatan ini dilakukan oleh teman sejawat selaku observer untuk mengamati aktivitas siswa. Pengamatan ini berlansung selama proses pembelajaran baik pada kegiatan awal, inti dan akhir. Pada Pada kegiatan awal terlihat secara keseluruhan siswa sudah siap mengikuti proses pembelajran, karena sudah terlihat dari kerapian tempat duduknya dan tidak ada aktivitas lain yang sifatnya mengganggu suasana selama proses pembelajaran. Namun ketika penyajian kelas, masih ada siswa yang tidak mendengarkan penjelasan yang disampaikan guru.

Begitu juga dalam langkah strategi belajar kooperatif tipe STAD selanjutnya. Dalam kegiatan belajar kelompok, siswa sudah mulai terbiasa belajar secara berkelompok. Hal ini terlihat dengan semua siswa sudah dapat menunjukkan sikap kerjasama dan mengerti akan tujuan kegiatan belajar kelompok yang dilakukan. Namun masih ada satu dua orang siswa yang kurang aktif.

Ketika penyampaian hasil diskusi kelompok semua kelompok sudah mulai berperan dan saat ditanya tanggapannya terhadap hasil diskusi yang telah disampaikan kelompok lain. Pada kegiatan akhir terlihat semua siswa menyimpulkan pelajaran dibawah bimbingan guru dan ketika diberi tes semua siswa dapat menyelesaikan dengan baik. 
Berdasarkan pengamatan terhadap aspek siswa, penilaian yang diberikan pengamat adalah 20 atau dengan persentase $71 \%$ dan bila disesuaikan dengan kriteria keberhasilan menurut BNSP (2006:12), maka penilaian terhadap aspek siswa adalah belum tuntas.

d. Refleksi

Kegiatan refleksi dilakukan secara kolaboratif antara praktisi dan guru kelas (observer) pada setiap akhir pembelajaran. Pada kesempatan ini temuan dan hasil pengamatan peneliti dibahas bersama. Refleksi tindakan siklus I pertemuan II ini mencakup refleksi terhjadap perencanaan, pelaksanaan, evaluasi, dan hasil yang diperoleh nsiswa.

Dari hasil paparan data siklus I pertemuan II diketahui bahwa pelaksanaan pembelajaran keliling dengan strategi belajar kooperatif tipe STAD sudah terlaksana dengan baik. Aktivitas dan hasil belajar yang diperoleh siswa sudah mulai meningkat.

Untuk memperbaiki kekurangan-kekurangan yang ada pada pertemuan II siklus I, peneliti akan kembali melaksanakan strategi belajar kooperatif tipe STAD ini pada siklus II pada materi pelajaran yang lain dengan lebih baik, yaitu keliling persegi panjang. Rencana perbaikan yang akan dilaksanakan adalah: (1) peneliti terus berusaha melaksanakan setiap langkah dari strategi belajar kooperatif tipe STAD dengan lebih baik dan memperbaiki kekurangan-kekurangan yang terdapat pada siklus I pertemuan II ini dan (2) peneliti berusaha mengamati setiap siswa secara keseluruhan, agar benar-benar dapat melaksanakan proses pembelajaran dengan sebaik-baiknya.

Selain itu peneliti ingin membuktikan proses pembelajaran dengan strategi belajar kooperatif tipe STAD dapat meningkatkan hasil belajar siswa secara keseluruhan, untuk itu peneliti merasa perlu melanjutkan pada siklus II.

\section{Hasil dan temuan penelitian siklus II}

\section{Perencanaan}

Perencanaan dalam pelaksanaan tindakan dimulai dengan mengambil satu kompetensi dasar kemudian dikembangkan dalam indikator. Kemudian dilanjutkan dengan membuat RPP yang utuh dan media yang sesuai dalam pembelajaran dan berdiskusi dengan guru kelas tentang waktu pelaksanaan tindakan.

2. Pelaksanaan

Pada kegiatan belajar kelompok ini siswa diberi kesempatan untuk lebih memahami materi yang sedang dipelajari dan guru berperan melatih siswa keterampilan kooperatif seperti bertanggung jawab terhadap tugas kelompok yang telah diberikan, mendorong semua siswa untuk berpartisipasi dalam diskusi kelompok dan mendorong siswa untuk bertanya bagi siswa yang kurang memahami materi pelajaran yang sedang dipelajari dengan teman sekolompoknya terlebih dahulu, serta jika teman sekelompoknya tidak mengerti barulah siswa dapat menanyakan lansung kepada guru. Selain itu, guru mengawasi setiap kelompok secara bergantian.

Didalam kelompok guru memberi setiap anggota kelompok LKS dan satu lembar jawaban, serta ringkasan materi yang bertujuan untuk memfokuskan siswa dalam diskusi kelompok dan untuk menyelesaikan LKS yang diberikan. Selain itu, guru melengkapi dengan lembar pengamatan siswa.

Setelah siswa selesai melaksanakan diskusi, semua kelompok diminta untuk menuliskan hasil diskusi kelompoknya dipapan tulis. Jika terdapat perbedaan hasil diskusi kelompok dengan hasil yang ditulis kelompok lain dipapan tulis, guru meminta tanggapan dari kelompok yang mempunyai hasil diskusi yang berbeda. Untuk meluruskan jawaban siswa, guru menggunakan kunci jawaban yang telah disediakan. Masing-masing kelompok memperbaiki jawaban yang dibuat dengan kunci jawaban.

Langkah selanjutnya tes individual, guru memberikan tes kepada siswa. Selama mengerjakan tes siswa tidak boleh saling membantu dan harus dikerjakan secara sendiri-sendiri. Kemudian tes yang telah dikerjakan siswa diperiksa guru. Dalam kegiatan ini guru menghitung peningkatan skor yang didapat siswa dari skor dasar sebelum pembelajaran.

Untuk menentukan kelompok yang memperoleh penghargaan didasarkan total skor peningkatan individu dalam kelompok. Dalam pemberian penghargaan guru berpedoman pada tabel perkembangan nilai siswa.

3. Pengamatan

Guru kelas berperan mengamati peneliti saat melakukan tindakan dan teman sejawat bertugas mengamati kegiatan siswa selama proses pembelajaran. Observer dalam melaksanakan tugasnya dibantu dengan lembaran pengamatan kegiatan yang diisi dengan memberi tanda ceklist baik pada aspek pengamatan guru maupun siswa dengan kriteria taraf keberhasilan yaitu Sangat Baik (SB), Baik (B), Cukup (C), Kurang (K). 
a. Penilaian RPP

Penilaian RPP mencakup lima hal yaitu kejelasan perumusan tujuan pembelajaran, pemilihan materi ajar dan pengorganisasian materi ajar, pemilihan sumber atau media belajar, kejelasan proses pembelajaran, dan penilaian hasil belajar. Dari penilaian pengamatan terhadap pelaksanaan tindakan dengan kesesuaian RPP dapat diambil kesimpulan.

Penilaian terhadap RPP yang diberikan oleh pengamat adalah 17 dengan persentase $85 \%$. Berdasarkan kriteria keberhasilan menurut BNSP (2006:12), maka penilaian yang diberikan terhadap RPP adalah sudah tuntas.

b. Aktivitas guru dalam proses pembelajaran

Aktivitas guru dalam proses pembelajaran pada siklus II ini sudah berjalan dengan baik dan sudah sesuai dengan rencana yang telah disusun sebelumnya, hal ini terlihat dari hasil belajar yang diperoleh siswa. Penilaian terhadap aspek guru yang diberikan oleh pengamat adalah 28 atau dengan persentase $87 \%$ dan kriteria keberhasilan menurut BNSP (2006:12) pengamatan terhadap aspek guru adalah sudah tuntas.

c. Aktivitas siswa dalam proses pembelajaran

Keterlibatan siswa juga diamati, kegiatan ini dilakukan oleh teman sejawat selaku observer untuk mengamati aktivitas siswa. Pengamatan ini berlansung selama proses pembelajaran baik pada kegiatan awal, inti dan akhir. Siswa sudah dapat mengikuti proses pembelajaran dengan baik dan menghindarkan hal-hal yang merugikan siswa seperti tidak memperhatikan guru ketika penyajian kelas tentang matri pelajaran yang akan didiskusikan. Tetapi disini terlihat siswa sudah mulai serius dalam mengikuti setiap langkah dari proses pembelajaran dan aktif dalam diskusi kelompok. Hal ini sangat berpengaruh terhadap hasil belajar yang makin meningkat yang dicapai siswa.

Penilaian yang diberikan oleh observer terhadap siswa adalah 24 atau dengan persentase $86 \%$. berdasarkan kriteria keberhasilan menurut BNSP (2006:12), maka penilaian terhadap aspek siswa adalah sudah tuntas.

4. Refleksi

Kegiatan refleksi dilakukan secara kolaboratif antara praktisi dan guru kelas (observer) pada setiap akhir pembelajaran. Pada kesempatan ini temuan dan hasil pengamatan peneliti dibahas bersama. Refleksi tindakan siklus II ini mencakup refleksi terhadap perencanaan, pelaksanaan, evaluasi, dan hasil yang diperoleh siswa.

Secara umum, proses pembelajaran pada siklus II ini sudah terlaksana dengan baik. Peningkatan yang berhasil dilakukan guru dalam pelaksanaan pembelajaran di siklus II ini, antara lain (1) Media yang digunakan sudah tepat dan sudah efektif penggunaannya, (2) Proses pembelajaran dengan mendiskusikan materi yang sedang dibahas, (3) Pembelajaran kooperatif tipe STAD menjadikan proses pembelajaran lebih menarik dan menyenangkan bagi siswa dan (4) Hasil tes siklus II menunjukkan bahwa jawaban siswa telah sesuai dengan apa yang diharapkan peneliti.

Hasil dari pertemuan II siklus I, siswa telah dapat mencapai ketuntasan $93 \%$ dan bahkan telah melampaui ketuntasan yang diharapkan BNSP (2006:12) yaitu $75 \%$. Oleh karena itu, siklus II ini hanya dilaksanakan dalam $1 \mathrm{x}$ pertemuan saja. Selain itu secara tidak lansung pelaksanaan proses pembelajaran siklus II ini menunjukkan bahwa strategi belajar kooperatif tipe STAD dapat terlaksana dengan baik dan mampu meningkatkan hasil belajar yang diperoleh siswa, bila dibandingkan dengan proses pembelajaran yang berlansung selama ini yaitu seraca konvensional.

\section{Pembahasan}

\section{Pembahasan siklus I}

Berdasarkan diskusi antara peneliti dan guru kelas III, penyebab belum terlaksana dengan maksimal proses pembelajaran karena siswa belum pernah belajar dalam kelompok belajar. Sehingga masih banyak siswa yang tidak mengerti dengan fungsi dan peranannya dalam diskusi kelompok.

Selain itu pengaturan posisi duduk siswa dalam belajar kelompok sebaiknya dilakukan sebelum siswa memasuki ruangan, sehingga ketika siswa memasuki kelas dapat lansung duduk dikelompoknya masingmasing. Pernyataan ini dipertegas oleh pendapat Suharsimi (2006:57) yang menyatakan "Dalam penelitian tindakan kelas dilakukan oleh guru, bekerja sana dengan peneliti dikelas tempat ia mengajar dengan penekanan pada penyempurnaan atau peningkatan proses dan praktispembelajaran." Pendapat yang senada diungkapkan oleh Masnur (2018:10) yang menyatakan 
Pada sisi lain, PTK akan mendorong para guru untuk memikirkan apa yang telah mereka lakukan seharihari dalam menjalankan tugasnya. Mereka akan kritis terhadap apa yang mereka lakukan tanpa bergantung pada teori-teori yang muluk-muluk dan bersifat universal yang ditemukan oleh para pakar peneliti yang sering kali tidak cocok dengan situasi dan kondisi kelas. Bahkan keterlibatan mereka dalam PTK sendiri akan menjadi pakar penetili di kelasnya, tanpa bergantung pada peneliti yang tidak tahu mengenai permasalahan di kelasnya masing-masing.

Sedangkan dari hasil penelitian siklus I pertemuan II yang dilakukan pada tanggal 23 Mei 2020, yang berlansung selama 3 jam pelajaran. Penerapan strategi belajar kooperatif tipe STAD sudah mulai terlaksana dengan baik. Dari lembar pengamatan aktivitas siswa dan hasil belajar yang diperoleh sudah mulai meningkat. Semua siswa sudah mulai tertibat aktif dalam prose pembelajran, walau masih ada satu dua orang siswa yang tidak mengikuti proses pembelajaran dengan serius. Dalam penyampaian hasil diskusi, semua kelompok sudah ikut berpartisipasi, pengelolaan kelas dan pengorganisasian siswa dalam duduk berkelompok tidak lagi menghabiskan waktu. Hasil belajar yang diperoleh siswa 7,7 dengan ketuntasan yang dicapai siswa $50 \%$. Ini berarti masih harus ditingkatkan. Berikut ini perbandingan hasil belajar yang diperoleh siswa dari hasil belajar sebelum dilaksanakan tindakan dan setelah siklus I.

Masukan yang didapat dari diskusi dengan guru kelas selaku observer selama pelaksanaan proses pembelajaran digunakan untuk perbaikan pada pertemuan berikutnya. Menurut guru kelas peneliti harus benar-benar menjadwalkan berapa lama waktu yang digunakan untuk suatu kegiatan sehingga tidak terkesan tergesa-gesa. Dari segi hasil belajar yang dicapai siswa sudah meningkat. Untuk memperbaiki kekurangan yang terjadi, peneliti melaksanakan siklus II, sebagai pembanding apakah strategi belajar kooperatif tipe STAD benar-benar dapat meningkatkan hasil belajar yang diperoleh siswa.

\section{Pembahasan siklus II}

Dari hasil penelitian siklus II yang dilaksanakan pada 30 Mei 2020. Pembelajaran keliling bangun datar pada siklus II ini dilakukan dalam satu kali pertemuan karena pada siklus I pertemuan II hasil belajar siswa sudah meningkat, maka siklus II ini dilakukan untuk membuktikan apakah hasil belajar siswa tetap meningkat dan pemahaman siswa terhadap materi menjadi semakin baik.

Hal ini terbukti dengan proses pembelajaran telah berjalan dengan lancar, begitu juga penilaian terhadap lembar pengamatan siswa dan guru juga sudah baik sekali. Karena selama proses pembelajaran siswa terlihat sudah mulai mengikuti pembelajaran dengan semangat dan semua siswa juga berkeinginan kelompoknya memperoleh nilai terbaik. Hal ini juga terlihat dari hasil belajar yang diperoleh siswa dengan nilai 8,6 dan ketuntasan belajar yang dicapai siswa yaitu $93 \%$, bahkan sudah melampaui ketuntasan yang diharapkan yaitu $75 \%$ sesuai BNSP (2006:12). Berikut ini perbanding hasil belajar yang diperoleh siswa dari hasil belajar sebelum dilaksanakan tindakan dan setelah pelaksanaan tindakan.

Ini membuktikan dengan strategi belajr kooperatif tipe STAD disamping dapat meningkatkan hasil belajar yang dicapai siswa, juga dapat memberikan kemampuan tambahan yaitu kemampuan bekerjasama dalam kelompok belajar demi keberhasilan kelompok, yang akhirnya semua anggota kelompok dapat memahami materi pelajaran yang sedang dibahas dengan baik. Selain itu juga membawa manfaat yang besar kepada siswa yang berkemampuan rendah karena dapat bertanya kepada teman anggota kelompoknya yang lain yang telah lebih dahulu memahami materi yang sedang di bahas.

Hal ini didukung oleh pendapat Muhammad (200:8) menyatakan "Melalui penerapan pembelajaran kooperatif siswa lebih mudah menemukan dan memahami konsep-konsep yang sulit dengan mendiskusikan masalah tersebut dengan temannya". Dengan demikian setelah pelaksanaan penelitian ini, diharapkan dapat diciptakan seorang guru profesional, yang mampu menyusun dan melaksanakan strategi dan pembelajaran yang aktif, inovatif, kreatif, efektif dan menyenangkan ( PAIKEM) yang dapat menggairahkan motivasi belajar siswa.

Dari keterangan tersebut, jelaslah bahwa dalam proses pembelajaran bukanlah sekedar kegiatan memindahkan pengetahuan dari guru ke siswa, tetapi sesuatu kegiatan yang memungkinkan siswa membentuk pengetahuan sendiri. Pernyataan ini didukung oleh pendapat Sadirman (2006:28) bahwa "Sebagai seorang guru propesional tidak hanya sekedar mengajar, tapi betul-betul sebagai pendidik yang memindahkan nilai-nilai (transfer of values) itu kepada anak didiknya". Selain itu, pendapat ini sesuai dengan penerapan strategi belajar koperatif tipe STAD pada penelitian ini. Karena peneliti melatih siswa keterampilan belajar kelompok, partisipasi kelompok dan menghargai pendapat orang lain. 


\section{Simpulan}

Berdasarkan penelitian yang telah dilakukan, dapat diambil beberapa kesimpulan yaitu : 1) perencanaan pelaksaan pembelajaran keliling bangun datar dengan menggunakan strategi belajar koperatif tipe STAD terdiri dari lima langkah yaitu penyajian kelas, belajar kelompok, tes, penentuan peningkatan individu dan menghargai kelompok. Keseluruhan langkah pembelajaran ini terlihat pada kegiatan awal, inti dan akhir; 2) Hasil belajar yang diperoleh siswa setelah menggunaka strategi belajar koperatif tipe STAD ini makin meningkat terlihat dari siklus I pertemuan I nilai akhir yang diperoleh siswa dari hasil tes dengan rata-rata 6,9 dan pertemuan II dengan rata-rata 7,7 dan haisl belajar ini terlihat makin meningkat pada siklus II yang mana nilai yang diperoleh siswa adalah 8,6.

\section{Referensi}

Asep Herry, dkk. (2007). Belajar dan Pembelajaran Sekolah Dasar. Bandung: UPI PRESS BSNP. (2006). Panduan Penyusunan Kurikulum Tingkat Satuan Pendidikan Dasar dan Menengah. Jakarta: BNSP Cholos Sa'dijah. (1999). Pendidikan Matematika 2. Jakarta: Depdikbud

Erna Suwangsih, dkk. (2006). Model Pembelajaran Matematika. Bandung: UPI PRESS

Etin Solihatin, dkk. (2007). Cooperative Learning Analisis Model Pembelajaran IPS. Jakarta: Bumi Aksara Faturocman. (2006). Rumus Metematika Lengkap SD. Jakarta: Wahyu Media

Hamzah B. Uno. (2006). Perencanaan Pembelajaran. Jakarta: Bumi Aksara

Hamzah B. Uno. (2008). Model Pembelajaran Menciptakan Proses Belajar Mengajar yang Kreatif dan Efektif. Jakarta: Bumi Aksara

Ida Wardani, dkk. (2007). Penelitian Tindakan Kelas. Jakarta. Universitas Terbuka

Ihat Hatimah, dkk. (2007). Penelitian Pendidikan. Bandung: UPI PRESS

Julius Hambali, dkk. (1991). Materi Pokok Pendidikan Matematika I, I-5. Jakarta : Departemen Pendidikan dan Kebudayaan

Jurumia. (2008). Meningkatkan Kompetensi Dasar Siswa dalam Merancang Penelitian Sosial Melalui Penerapan Model Pembelajran Kooperatif Tipe STAD. Jakarta:Jurnal Pendidikan Edisi Oktober 2008 Tahun Ke 1 Nomor 2

Made Wena. (2018). Strategi Pembelajaran Inovatif Kontemporer. Jakarta:Bumi Aksara

Mansur Muslich.(2018).Melaksanakan PTK (Penelitian Tindakan Kelas) itu mudah. Jakarta: Bumi Aksara

Moedjiono. (1993). Strategi Belajar Mengajar. Jakarta: Departemen Pendidikan dan Kebudayaan Diktorat Jenderal Pendidikan Tinggi Proyek Pembinaan Tenaga Kependidikan

Mohammad nur. (2000). Pengajaran Berpusat Kepada Siswa dan Pendekatan Kontruktivis dalam Pengajaran. Surabaya: Universitas Negeri Surabaya

Mulyana AZ. (2007). Trik dan Tip Berhitung Super Cepat dengan Konsep Rahasia Matematika untuk SD Kelas 3 , 4,5, dan 6 Guru dan Murid SD. Surabaya: Agung Media Mulya

Mulyasa. (2007). Kurikulum Tingkat Satuan Pendidikan Sebuah Panduan Praktis. Bandung : PT Remaja Rosda Karya

Nana Sudjana. (2004). Penilaian Hasil Proses Belajar Mengajar. Bandung : PT Remaja

Nurasma. (2008). Model Pembelajaran Kooperatif. Padang : unp press

Nurhadi, dkk. (2003).Pembelajaran Kontektual (Contextual Teaching and Learning/CTL) dan Penerapan dalam $K B K$. Malang: Univesitas Malang Press

Oemar Hamalik. (1999). Kurikulum dan Pembelajaran. Jakarta:Bumi Aksara

Oemar Hamalik. (2008). Perencanaan Pengajaran Berdasarkan Pendekatan Sistem Bandung: Bumi Aksara

Pitajeng. (2006). Pembelajaran Matematika yang Menyenangkan. Jakarta: Departemen Pendidikan Nasional Direktorat Jenderal Pendidikan Tinggi Diktorat Ketenagaan

Ritawati Mahyuddin. (2008). Hand Out Mata Kuliah Metedologi Penelitian Tindakan Kelas. Padang: FIP UNP

Russeffendi.(1992).Materi Pokok Pendidikan Matematika 3. Jakarta : Depdikbud

Ruswandi Hermawan, dkk. (2007). Metode Penelitian Pendidikan Sekolah Dasar. Bandung: UPI PRESS

Sadirman. (2006). Interaksi dan Motivasi Belajar-Mengajar. Jakarta :PT Raja Grasfindo Perseda

Slavin Robert E. (1995). Cooperative Learning Theory, Researsh, And Practicesecond Edition. Boston:Allyn and Bacon

Sri subarinah. (2006). Inovasi Pembelajaran Matematika Sekolah Dasar. Jakarta: Depertermen Pendidikan Nasional Dikrektoratjenderal Pendidikan Tinggi Direktorat Ketenagaan

Sudarmawan Danim. (2002). Menjadi Peneliti Kualitatif. Bandung: CV Pustaka Setia

Suharsimi. (2006). Prosedur Penelitian Suatu Pendekatan Praktis. Jakarta : Rineka Cipta

Suharsimi. (2006). Penelitian Tindakan Kelas. Jakarta : Bumi Aksara 
Tim Pembina Mata Kuliah Pengantar Pendidikan. (2006). Bahan Ajar Pengantar Pendidikan. Padang: Fakultas Ilmu Pendidikan

Tim Penyusun Kamus Besar Bahasa Indonesia. (2007). Kamus Besar Bahasa Indonesia. Jakarta: Balai Pustaka Wina Sanjaya. (2007). Strategi Pembelajaran Berorientasi Standar Proses Pendidikan. Jakarta: Kencana 